\title{
The Development of the Species of Upogebia from Plymouth Sound.
}

\author{
By \\ Gladys E. Webb. \\ Temporary Assistant Naturalist at the Marine Biological Laboratory, Plymouth.
}

With Plates I-XII.

Upogebia deltura Leach and Upogebia stellata (Mont.) are both of common occurrence on the coasts of Devonshire and Cornwall, but in the adult stage they are not easily obtained, owing to their burrowing habits.

The larvæ, however, are very common in the tow-nets, occurring throughout the year with the exception of the midwinter months, and are particularly plentiful from June to August.

The two species are closely allied, and for some time it was believed that the differences between them might be merely sexual, and not specific (Bell 1853). They are now clearly recognised as separate and distinct species, and De Morgan (1910) has obtained males and females of both forms.

Upogebia deltura Leach may be distinguished by its greater size, sometimes five or six inches in length when full-grown, as well as by its broad abdomen with soft abdominal pleura. The two joints of the chela on the first thoracic leg are almost equal in length.

Upogebia stellata (Mont.) is an altogether smaller and more slender animal, seldom exceeding two and a half inches in length. The abdomen is narrower, and the fixed finger of the chela very much shorter than the dactylus, There is also a small point on the side of the carapace, just over the base of the second antenna, which has been established as a specific character by De Morgan (1910).

In the living state the body of the animal is covered with orange-red spots (hence its name stellata), while Upogebia deltura Leach is of a uniform dirty cream colour.

They live in long burrows beneath the mud, $U$. stellata being the more common in this district, and a day's digging in the mud flats 
uncovered by low tides at Salcombe may yield about a dozen specimens of both species.

The four larval stages and two or three early post-larval stages of both species are here described and figured. A careful table of comparison has been drawn up between the two British species and the Norwegian form whose development has been recorded by Sars (1884).

Several features of special interest in the development have been noted as possibly indicating that sex differentiation commences at a very early period-perhaps right from the beginning of the larval development-and that the two sexes differ in the number of moults they undergo during the larval life.

I am indebted to Dr. M. V. Lebour for looking after the experiments during my absence in July, and to Mr. De Morgan for the loan of some preserved specimens of the first larval stage of Upogebia stellata which he hatched last year from a berried female, in the Laboratory.

My thanks are also due to Dr. Calman for his kindness and courtesy in allowing me to examine numerous specimens from the British Museum collections.

\section{METHODS.}

The larvæ were taken from the tow-nets and the various stages placed in separate jars filled with sea-water from beyond the Breakwater. To prevent confusion, the different jars were labelled by means of small pieces of porcelain numbered and sunk in each jar; they were stood in one of the tanks in the Laboratory and kept aerated by means of porous air-nozzles.

The larvæ were taken out every day and examined in a watch-glass under the microscope; moults, if any, were removed, and the water partly renewed.

A careful record of the various stages and their moultings was kept. In this way the consecutive stages were plainly determined.

When they reached the first post-larval stage, they were removed from the jars and placed in shallow glass dishes filled with sea-water, with a little sand and vegetable débris from one of the tanks at the bottom.

Specimens were generally preserved in $5 \%$ formalin and then transferred to $70 \%$ alcohol. Moults were placed directly in $70 \%$ alcohol.

Dissections from which drawings were made were mounted either in water or, if a permanent preparation was desired, in glycerine jelly. Those parts not surrounded by a chitinous skeleton (e.g. the developing endopodites of the thoracic limbs) were always mounted in water, as they were found to shrink in a glycerine mount.

Drawings were made to scale on squared paper by the use of a squared eye-piece fitted into the microscope. 


\section{NOMENCLATURE.}

Although several məmbers of the genus Upogebia have been known for over a century, yet considerable confusion appears still to exist as to the correct application of the specific names stellata, deltura, and littoralis.

The species Upogebia stellata was first described by Montagu from the south coast of Devonshire in 1805, under the name of Cancer Astacus stellatus.

In 1813 Leach removed it from this position in the Crustacea, and re-named it Upogebia stellata, its correct name being now Upogebia stellata (Mont.).

In a paper read before the Linnean Society in 1814, and published in the following year (1815) Leach altered his own generic name from Upogebia to Gebia. The former name, however, has the precedence, and must therefore be considered correct.

The second species was first described by Leach in the same paper under the name of Gebia deltaura, presumably in reference to the deltoid shape of the inner uropod.

In the Malacostraca Podophthalmata Britanniæ (1815-17), however, he refers to it under the title of Gebia deltura. Thus the specific name of deltaura actually has the precedence over deltura, but as it was corrected by Leach himself, and as the animal is commonly known and referred to as deltura, it is here called Upogebia deltura Leach, in deference to an established name.

The name Gebiopsis was first used by A. Milne Edwards in 1868, and in 1903 Borradaile suggested the subdivision of the genus Upogebia into two sub-genera-Gebiopsis and Upogebia; thus the nomenclature of the British species would be

\section{Upogebia (Gebiopsis) deltura Leach}

and Upogebia (Upogebia) stellata (Mont.).

This subdivision bas not been followed in this paper, as the characters on which it is based are inconspicuous, and considered of insufficient importance to warrant the establishment of a separate sub-genus.

The third specific name, littoralis, was first applied by Risso in 1816 to a specimen from the neighbourhood of Nice, which he called Thalassina littoralis.

In 1825 it was brought into the genus Gebia by Desmarest, and it has been fairly fully described by Heller in 1863, in his "Crustaceen des südlichen Europa."

Its larval stages have been described by Cano, from the Mediterranean, in 1891.

The descriptions of this Mediterranean species all seem to denote 
an animal very similar to Upogebia stellata (Mont.) with the exception of the following points-the colour of the Mediterranean species is a uniform greenish grey, while the English species is well known to be thickly covered with bright orange-red spots.

The base of the first antenna in Gebia littoralis (according to Heller) is longer than the two flagella, while in both Upogebia stellata and deltura it is considerably shorter.

The British Museum collection contains about ten specimens of this genus from the Mediterranean, all of $\mid$ which come from the Market, Malta. These have been examined, and found to be all specimens of Upogebia deltura Leach, displaying the long fixed finger of the chela, and the absence of the supra-antennal point which are the characteristics of this species. (See De Morgan 1910.)

G. O. Sars has written an account of the larval development of a species of Gebia, which he calls Gebia littoralis Risso (1884). Meinert, in his "Hauch's Togter" (1893), states that he obtained two young specimens, which he identified as the species described by Sars, and calls Gebia stellata Mont, believing the two species to be synonymous. In a later paper by Stephensen on the marine decapods of Denmark (1909), this species Gebia littoralis of Sars is again given as a synonym of Gebia stellata Mont. Stephensen, however, who has evidently examined the two specimens from the Hauch's cruise, notes certain differences in one specimen from the Norwegian species, which indicate that the animal in question was a first post-larval stage of Upogebia deltura Leach, Form B, and not Gebia littoralis of Sars.

Although both Meinert and Stephensen give Gebia littoralis of Sars as a synonym of Upogebia stellata (Mont.), yet a comparison of Sars' figure of the first thoracic leg of the animal in the first post-larval stage (Tab. 5, Fig. 13) with that here shown of the same limb in Upogebia stellata (Pl. XI, Fig. 3) exhibits a striking difference in general build, and especially in the relative lengths of the dactylus and the fixed finger of the claw.

Other differences occur in the larval stages, noticeably the plumose seta on the second joint of the endopodite of the first maxilliped in stages one and two of Upogebia stellata, and the different number of plumose setæ on the exognath of the second maxilla.

Thus it seems certain that Gebia littoralis of Sars cannot be identified with Upogebia stellata (Mont.); yet neither does Sars' account exactly agree with the description here given of the development of Upogebia deltura Leach-the greater number of plumose setæ on the exognath of the second maxilla, and of denticles on the fixed finger of the chela in the first post-larval stage of Sars' species being two points of difference.

These facts seem to denote that Sars' description refers to neither of 
the British species [Upogebia stellata (Mont.) and Upogebia deltura Leach], but to a different and possibly purely Norwegian form.

Risso's original description of Thalassina littoralis (1816) gives insufficient details to enable one to identify it with certainty, but it seems very unlikely that the same species should occur both in Norway and the Mediterranean, and not on the British coasts.

Risso's Var. A., which he notes as " une très belle thalassine d'un rouge carmin plus ou moins foncé avec l'abdomen d'un blanc nacré," may possibly be Upogebia stellata (Mont.).

There appear therefore to be four distinct European forms, two of them at least constituting well-defined species.

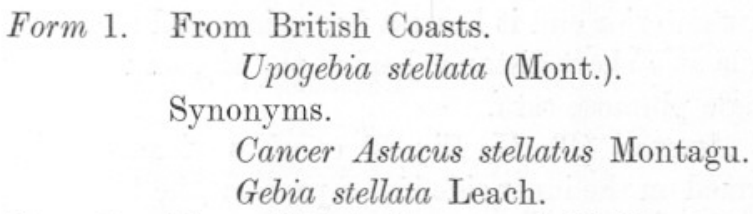

Form 1. From British Coasts.

Upogebia stellata (Mont.).

Synonyms.

Cancer Astacus stellatus Montagu.

Gebia stellata Leach.

Form 2. From British Coasts and Mediterranean.

Upogebia deltura Leach.

Synonyms.

Gebia deltura Leach.

Gebiopsis deltura Stephensen.

Form 3. From Mediterranean.

Gebia littoralis (Risso).

Synonyms.

Thalassina littoralis Risso.

Gebia littoralis Desmarest.

Gebia litoralis Heller.

Form 4. From Norway.

Gebia littoralis of Sars.

A careful comparison of Norwegian and Mediterranean specimens is necessary betore the true value or position of the two latter forms is ascertained.

\section{UPOGEBIA DELTURA LEACH.}

\section{First Larval Stage (Pl. I, Fig. 1).}

The first larval stage which occurs in the tow-nets measures about $2 \frac{1}{2} \mathrm{~mm}$. in length from the tip of the rostrum to the end of the swimming plate. In general appearance it resembles certain species of Hippolyte, and Dr. M. V. Lebour's reference (1917) to "Macruran larvæ indet. chiefly allied to Hippolyte, common in July and August," probably 
refers to the early larval stages of this and the allied species Upogebia stellata (Mont.)

In colour the larva is almost perfectly transparent, with a few bright red chromatophores on the antennæ and thorax, and one at the base of the swimming plate.

The carapace is smooth, rounded behind and at the sides, and produced in front into a moderately acute rostrum, which reaches well beyond the eyes.

The eyes are large, of the usual decapod crustacean type, and fixed on short immovable stalks which are united with each other at the base.

The First Antenna (Pl. II, Fig. 1) is a simple unjointed process about $0.4 \mathrm{~mm}$. in length, projecting forwards on either side of the median line in front. At its anterior end it bears a few spines and a long ribbon-like æsthotasc, while at a short distance behind the tip, on the inner side, is attached a single plumose seta.

The Second Antenna (Pl. II, Fig. 2) consists of an unjointed base, which is continued on the inner side into a process (the flagellum) bearing three plumose setæ at the end, and on the outer side into a flat oval plate (the antennal plate) reaching somewhat beyond the flagellum, and terminating in a small spine. The outer margin of the antennal plate is smooth and somewhat arched, but round the tip and along the inner edge is attached a row of nine long plumose setæ. On the ventral surface of the base, just behind the junction of the antennal plate, is a tooth-like spine.

The Mandibles (Pl. II, Fig. 3) are of moderate size, with a strongly chitinised and toothed inner border, and united by the lower lip.

The First Maxilla (Pl. II, Fig. 4) is composed of a basal portion, produced on its inner margin into two lobes of sub-equal size, both of which are thickly set with coarsely barbed spines, ${ }^{*}$ and a three-jointed process, or palp, at the tip, also bearing spines though of a rather more slender kind than those on the basal lobes.

The Second Maxilla (Pl. II, Fig. 5) is more membranous in character, and bears on the inner surface a maxillary palp in front and four masticatory lobes behind, of which the hindmost is the largest, and all of which (including the palp) are thickly set with coarsely barbed spines. On the anterior part of the outer edge is attached a flattened oval lobe, the exognath, around the margin of which are fixed nine plumose setæ.

The First Maxilliped (Pl. II, Fig. 6) consists of a two-jointed base or protopodite, from which spring a five-jointed endopodite and a two-

* The term "plumose" is used here to denote those feather-like setæ which are armed with fine regular hairs, while "barbed" is used to describe the coarser and more irregular arrangement of hairs on certain spines (e.g. in Pl. II, Fig. 14, the spines along the inner surface of the endopodite are barbed, while the long setæ at the end of the exopodite are plumose). 
jointed exopodite, terminating in four long plumose setæ and serving as a swimming paddle. Arranged in pairs along the inner margin of the endopodite and the base, are numerous coarsely barbed spines; one pair on the first basal joint (coxopodite) four pairs on the second joint (basipodite) while all the joints of the endopodite except the third and the last, bear one pair each. The last joint bears two pairs in a cluster at the tip, and the third has only a single short one. On the outer surface of the last joint of the endopodite is attached a short plumose seta.

The Second Maxilliped (Pl. II, Fig. 7) closely resembles the first, with a few differences of detail. The endopodite is only four-jointed, and the barbed spines are more sparsely distributed, especially on the basal portion, while the coxopodite is entirely bare of spines.

Behind the second maxilliped, decreasing in size from before backward, appear the rudiments of the remaining thoracic limbs (Pl. XII, Fig. 1) of which the first four pairs are already bifid, and the two last pairs simple and very small.

The Abdomen is long, composed of six segments and slightly tapering towards the posterior end. The last abdominal segment is produced into a flattened swimming plate (Pl. II, Fig. 8) of a roughly triangular shape, on the ventral surface of which, covering the opening of the anus, is a single median tooth-like spine.

The hind margin of the swimming plate is indented in the middle line, and on either side of this median " notch " are five long plumose spines arranged at regular intervals, while at the outer corner is a short toothlike spine.

There is as yet no trace of abdominal limbs.

\section{Second Larval Stage (Pl. I, Fig. 2).}

This larva, obtained directly from the moulting of that of the first stage, shows an increase in size, but nevertheless bears a strong resemblance to the previous stage. The most noticeable difference is the increased number of exopodites furnished with terminal swimming setæ.

On examining a considerable number of larvæ of this stage, it was found that instead of being all exactly similar, they fall into two classes, differing in the number of setose exopodites and in the development of the true walking legs (endopodites).

An individual of the first class (Class A) has four pairs of exopodites, furnished with swimming setæ (the three pairs of maxillipeds and the first pair of legs) while that of the second (Class B) has, in addition to these, two terminal setæ on the second pair of legs, making five pairs in all.

Moreover, individuals of Class A occasionally bear an additional seta 
on the first pair of legs (six setæ instead of five) while this extra seta is almost always present in members of Class B.

Thus the total number of limbs furnished with swimming setæ in the two classes is as follows :-

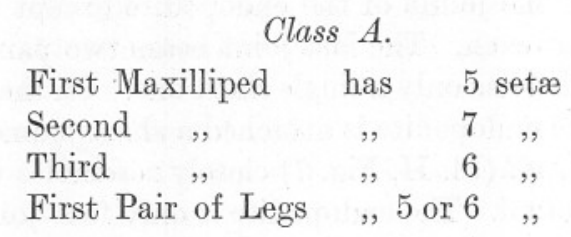

Class $B$.

$\begin{array}{lccc}\text { First Maxilliped has } & 5 & \text { setæ } \\ \text { Second , } & , & 7 & , \\ \text { Third ", } & , & 6 & , \\ \text { First Pair of Legs , } & 6 & , \\ \text { Second,, , } & , & 2 & ,\end{array}$

In correlation with this increased development of the thoracic exopodites, the endopodites in the second class are considerably more advanced both in size and structure, and the abdominal limbs, which in Class A do not project through the cuticle, stand out freely from the four middle abdominal segments in members of this class. (Pl. III, Fig. 11-only three segments shown.)

There is very little difference in size between the two kinds of larvæ, Class B being generally slightly the larger, and apart from the differences here cited they appear to be entirely similar, so that one description serves for both.

The larva at this stage measures just over $3 \mathrm{~mm}$. in length from the tip of the rostrum to the end of the swimming plate. The general shape of the body is little altered from that of the previous stage, save for a slight increase in the relative length of the abdomen, which gives the animal as a whole a more slender appearance.

The rostrum reaches well beyond the eyes, almost half-way up the shaft of the first antenna.

The eyes are large, and united only by a narrow connection at the base.

The First Antenna (Pl. II, Fig. 9) shows a great advance in complexity on that of the previous stage. It now consists of a main stem or shaft, from which two conical processes or palps are cut off at the anterior end; of these the outer is distinctly the larger, and furnished with a few scattered spines and three long ribbon-like æsthotascs, while the inner one is terminated by a single plumose seta. On the inner border 
of the shaft are attached two long plumose setæ, and opposite the more anterior of these is a spot from which spring a few weak spines.

The Second Antenna (Pl. II, Fig. 10) is not much changed; but the flagellum is now cut off from the base, and the inner margin of the antennal plate bears eleven plumose setæ. In addition to the spine on the ventral surface of the base, there is another similar spine on the outer border of the base, just below the junction of the antennal plate.

The Mandible (Pl. II, Fig. 11) is rather longer than before, and has developed a beak-like prominence on the inner border.

The First Maxilla (Pl. II, Fig. 12) is very similar to that of the first stage, though somewhat larger.

The Second Maxilla (Pl. II, Fig. 13) has much the same appearance as in the last stage, but the spines are more thickly set, and the exognath bears eleven or twelve setæ, in place of the nine previously present.

The First Maxilliped (PI. II, Fig, 14) has one more plumose seta at the end of the exopodite, making five in all ; otherwise it is unchanged.

The Second Maxilliped (Pl. II, Fig. 15) has an increased number of swimming setæ, of which there are now seven on the exopodite.

The remaining limbs differ in their degree of development in the two classes.

The Third Maxilliped (Pl. III, Figs. 1, 2) has a two-jointed base, from which spring two processes, the two-jointed exopodite, similar to those of the other two pairs of maxillipeds, and bearing six plumose setæ at the end, and the developing endopodite, which in Class A (Fig. 2) does not quite reach to the end of the basal joint from which it springs, but in Class B (Fig. 1) exceeds it in length. It bears a single plumose seta near the end.

The First Leg (Pl. III, Figs. 3, 4) is constructed on a similar plan, but in Class A (Fig. 4) the endopodite reaches to the end of the first joint of the exopodite, while in Class B (Fig. 3) it distinctly exceeds the exopodite in length, and shows near the tip on the inner surface the first signs of the formation of the fixed finger of the chela.

The Second Leg (Pl. III, Figs. 5, 6) displays an even more striking difference between the two classes, for in Class A (Fig. 6) it is merely a deeply biturcated process, unsegmented save for the single division at the base, and bearing no setæ of any kind; while in Class B (Fig. 5), on the other hand, it is almost as well developed as the third maxilliped, and the endopodite is longer than the exopodite, which bears two plumose setæ of moderate- length.

The following three pairs of thoracic limbs, of which the first pair is bifid (Pl. III, Figs. 7, 8) show once more a greater development in Class B (Fig. 7) than in Class A (Fig. 8).

The abdomen is long and tapering towards the posterior end, and, 
in Class B, each of the four middle segments bears a pair of blunt, forwardly directed outgrowths which are the rudiments of the future pleopods (Pl. III, Fig. 11). In Class A they have not yet pierced the cuticle.

The swimming plate (Pl. III, Figs. 9, 10) in both classes is almost the same shape as in stage one, but on the centre of the hind border, where the median "notch" (in Class A practically effaced, Fig. 9) is situated, there are three very small spines, one median, and one on either side. This brings the total number of spines up to fifteen. Within the cuticle can be seen quite distinctly the developing uropods of the following stage.

\section{Third Larval Stage (Pl. I, Fig. 3).}

The two classes of larvæ noted in stage two are still present in stage three, but they are not so readily distinguished from each other, because their chief mark of distinction lies in the degree of development reached by the endopodites of the thoracic limbs; and as these, being only covered by a soft skin and not by a rigid cuticle, grow considerably in size during the progress of the larva from one moult to the next, it is difficult to distinguish with certainty a young third stage larva of Class B from an older one of Class A.

Both classes of larvæ have been obtained directly from the moulting of second stage larvæ during the course of the experiments, but actual proof that a Class A third stage larva always results from the moulting of a Class A second stage larva, and similarly with Class B, has not yet been established owing to the difficulty above mentioned of distinguishing the two classes of third stage larvæ until they are approaching the next moult, when the new appendages may be perceived through the cuticle of the old. This serves as a means of distinction, because at this moult the two kinds of larvæ pursue different courses of development, those belonging to Class A moulting into a fourth larval stage which closely resembles the third, while those of Class B moult directly from the third larval stage into the first post-larval stage, thus missing entirely the fourth larval stage.

That this is actually the case has been proved many times during the rearing of the larvæ in the Laboratory, and numerous moults from both $A$ and $B$ forms have been obtained. Third stage larvæ were isolated in jars of sea-water, and removed daily for examination under the microscope, and when they moulted the skins were taken out and preserved in $70 \%$ alcohol.

Between August 9th and October 17th, 1918, the records kept give a total of nine moults from the third to the fourth larval stage, ten from the fourth larval to the first post-larval stage (Class A) and fourteen 
moults direct from the third larval stage to the first post-larval stage (Class B).

Moreover, in several cases, when the animal was unable to complete the moult, a post-larval stage not yet entirely freed from the third stage larval skin was obtained, a fact which must be considered as proof positive that such a moult aetually does take place.

The post-larval forms thus obtained from Class B were in no way deformed or abnormal, nor were they less active and vigorous than those which had passed through four larval stages, although they were slightly smaller, and differed from the others in a few structural details (see descriptions).

The following description applies to both A and B Classes.

The animal in the third larval stage measures about $3 \frac{1}{2} \mathrm{~mm}$. in length, but a much greater amount of variation is apparent in this than in either of the preceding stages. It shows certain definite signs of progress on the previous stage, notably the presence of six pairs of setose exopodites on the thoracic limbs, and of two pairs of uropods, which stand out on either side of the telson.

The rostrum is acute, reaching to about one-third of the length of the first antenna; the eyes are large and completely separated from one another at the base.

The First Antenna (Pl. IV, Fig. 1) is much the same shape as in the previous stage, but considerably longer and stouter. There are five plumose setæ (or occasionally four) on the inner border, and three more on the anterior end of the shaft, just over the junction of the palps with the stem, making eight setæ in all. The outer edge has two or sometimes three offsets marked by a cluster of weak spines, and the base exhibits a slight swelling, within which is forming the auditory organ of the adult.

The Second Antenna (Pl. IV, Fig. 2) is very similar to that of the preceding stage, but the number of plumose setæ on the antennal plate has increased to thirteen or fourteen, while the flagellum now forms a tapering process almost as long as the plate, and tipped with a single spine.

The Mandible and First Maxilla (Pl. IV, Figs. 3, 4) have not altered materially in appearance.

The Second Maxilla (Pl. IV, Fig. 5) is still the same general shape, but the exognath has developed a posterior lobe, and bears twelve to fifteen plumose setæ.

The three pairs of Maxillipeds (Pl. IV, Figs. 6-9) have altered very little, the only differences being the presence of an additional seta on the exopodites of the first and third pair, making the total number on the three pairs respectively six, seven, and seven; also the appearance 
of a plumose seta on the outer surface of the second joint of the endopodite in the first Maxilliped.

This seta is of some importance, because it is also present in the first and second larval stages of Upogebia stellata; and thus serves as an easy mark of distinction between the first two larval stages of the two species. The plumose seta tipping the endopodite of the third maxilliped is not always present in this stage (Figs. 8, 9).

The first three pairs of thoracic legs (Pl. V, Figs. 1-6) are now provided with setose exopodites, of which the first and third have seven and five setæ respectively, while the second may have either five or six. The development of the endopodites varies according to the class and the age of the larva, but Class A (Figs. 2, 4,6) never attains such a high degree of development as that reached by members of Class B before moulting (Figs. 1, 3, 5).

All the endopodites except that of the third maxilliped are wholly without spines; the two last pairs of thoracic legs are uniramous and carried pointing forwards beneath the others (Pl. XII, Fig. 3).

The Pleopods vary in length; in advanced stages of Class B they may extend over two segments. In such cases they exhibit a swelling on the inner side near the base, representing the inner lappet of the pleopod in the future post-larval stage.

The pleopods are carried pointing forwards and are still quite immovable.

The Uropods (Pl. IV, Fig. 10) are attached to the last abdominal segment, and are not yet entirely separated from each other, the inner one forming a mere spineless outgrowth of the outer and larger uropod, which is bare of spines on the outer margin, but furnished at the tip and along the inner edge with a row of twelve to fourteen plumose setæ.

The Telson (Pl. IV, Fig. 10) is roughly oblong in shape, rather wider towards the distal end, which is weakly concave, and produced at each corner into a strong toothed spine. In the median line is a small toothshaped spine, and on either side of this are four medium plumose spines of a similar kind. Outside the corner spines, on the lateral border of the telson, are two, or occasionally three, small spines on either side.

\section{Class A only.}

Fourth Larval Stage (Pl. I, Fig. 4).

The fourth and last larval stage may be readily distinguished from the preceding one by the full development of the inner pair of uropods, as also by the increased size of the endopodites of the thoracic limbs (PI. XII, Fig. 4) and of the abdominal appendages.

The larva is now just over $4 \mathrm{~mm}$. in length and the general body form is unaltered save for a broadening of the fore part of the abdomen. 
The rostrum and eyes are unchanged.

The First Antenna (Pl. VI, Fig. 1) has developed another plumose seta on the inner border of the shaft, making nine in all.

The Second Antenna (Pl V, Fig. 7) still has fourteen (occasionally fifteen) plumose setæ on the antennal plate, which is now distinctly overtopped by the flagellum.

The Mandible (P1. VI, Fig. 2) is larger, but otherwise unaltered.

The First and Second Maxilla (Pl. V, Figs. 8, 9) present an unchanged appearance, save for the increased development of the exognath on the second maxilla, which now bears about eighteen plumose setæ.

The number of setæ on the six pairs of swimming exopodites has increased to seven on all but the first pair of maxillipeds, which have only six.

The First and Second Maxillipeds (Pl. VI, Figs. 3, 4) are otherwise unchanged.

The Third Maxilliped (Pl. VI, Fig. 5) generally lacks the plumose seta at the end of the endopodite. The remaining thoracic limbs, of which the first three pairs are furnished with swimming exopodites (Pl. VI, Figs. 6-8) are larger than in the previous stage, but still quite spineless.

The Pleopods are still immovable, but have increased slightly in length.

The Uropods (Pl. V, Fig. 10) are now mounted on a distinct basal joint; the inner pair is separated from the outer and attached to the base independently; it is nearly as long as the outer, and bears at the tip and along the inner margin a row of about thirteen plumose setæ.

The Telson (Pl. V, Fig. 10) is considerably longer and narrower than in the preceding stage, but the arrangement of the spines, which are no longer plumose, is similar.

\section{First Post-larval Stage (Pl. X, Fig. 1).}

At this stage of its life history the animal undergoes a sudden and very striking change both in appearance and habits. Hitherto it has been a free-swimming pelagic larva, living at or near the surface of the sea, swimming actively by means of its six pairs of well-developed exopodites, and feeding probably on diatoms and other unicellular planktonic organisms.

In its next stage it becomes a typical Decapod crustacean, pale pink in colour and very hairy, with a well-developed flattened abdomen bearing four pairs of swimming pleopods, and with a powerfully chelate first pair of legs and four more posterior pairs, all of which show some adaptation to fossorial habits. The animal instead of swimming near the surface, sinks to the bottom and burrows in the sand or mud. 


\section{Class B.}

From the tip of the rostrum to the end of the telson it measures about $3 \frac{1}{2} \mathrm{~mm}$. The carapace is strongly compressed laterally, so that its height considerably exceeds its breadth; and it is produced in front into a short rostrum which terminates behind the level of the end of the eyes in an upwardly directed point (Pl. VII, Fig. 1).

The abdomen is long and flattened dorso-ventrally; it comprises six segments, of which the middle four each bear a pair of very hairy swimming pleopods, and the last bears the two pairs of uropods. The telson is short and broad, and is generally carried flexed beneath the abdomen, by means of a quick straightening and reflexing of which the animal can dart backwards with great rapidity if alarmed.

The First Antenna (Pl. VII, Fig. 2) projects in front on either side of the rostrum; it bears a general resemblance to the antennæ of the Brachyura, being very short and more or less bent into a knee-shape. The first joint is swollen at the base, and contains an auditory organ ; on the anterior outer corner of this joint is a strong tooth-like spine. The second joint is smaller, and produced at its anterior inner corner into a short process bearing a tuft of spines. The third joint is almost as long as the first, and is bent on the second to form with that joint a rather wide angle. At the tip it bears a short palp tipped with spines, and a three-jointed process, on which are three long ribbon-like æsthotases and a few scattered spines.

The Second Antenna (Pl. VIII, Fig. 3) is long and slender, and projects forwards and outwards beneath the eyes. Each is composed of a stout four-jointed base or shaft, and a long whip-like flagellum, of about sixteen joints. The fourth joint of the shaft bears a crown of spines, and on about every other joint of the shaft is a similar ring of spines. On the outer surface of the second joint of the shaft is a small process which represents the remains of the antennal plate.

The Eyes (Pl. VII, Fig. 4), though relatively much smaller than those of the larva, still reach beyond the end of the rostrum, and in most cases they cover the first antenna up to the terminal palps, and the second antenna to beyond the first joint of the flagellum.

The Mandible (Pl. VI, Fig. 9) is much the same shape as that of the larva, but it has a mandibular palp on the anterior surface, tipped with a few short spines.

The First Maxilla (Pl. VII, Fig. 5) has two masticatory lobes, of which the basal one is much the larger and triangular in shape. It bears a few short spines on its inner edge. The other is somewhat enlarged at the tip, which is beset with a number of similar short spines. The maxillary 
palp is reduced to a spineless process on the outer side of the smaller masticatory lobe.

The Second Maxilla (Pl. VII, Fig. 6) has altered very little in form from that of the larval stages. It still has four masticatory lobes on the inner border, of which the two innermost are very narrow.

The masticatory lobes are, however, much more sparsely set with spines than in the previous stages, the first three lobes bearing only a few short spines, while the last and largest lobe is entirely naked. In front of the masticatory lobes projects inwards a rather slender maxillary palp, with a single plumose seta near the end. The exognath is well developed and bears along its margin about twenty-nine plumose setæ.

The First Maxilliped (Pl. VII, Fig. 7) is much reduced in size. The two basal joints are produced inwards to form two masticatory lobes, fairly thickly beset with spines. The palp is reduced to a short spineless process which seems to show some slight signs of division into three parts, and the exognath, which is a little longer than the palp, bears on its outer surface four curved and finely barbed setæ.

The Second Maxilliped (Pl. VII, Fig. 8) is slightly larger than the first. It consists of a single basal joint, which bears a five-jointed palp and a simple exognath. The palp, of which the second joint is distinctly the longest, is curved inwards on itself. A few rather short spines are situated on the inner border of the first and second joints, while two very long, curved, and finely barbed setæ are borne on the outer surface of the penultimate joint. The exognath is a slender spineless process, springing from the outer surface of the first joint of the palp, and pointing forwards.

The Third Maxilliped (Pl. VII, Fig. 9) is distinctly the longest of the three, and is constructed on a plan similar to the preceding, but may be distinguished from it by the much stronger development of the inner branch or palp. This is composed of five joints, of which the second is the longest, and the two last joints are both fairly thickly set with rather strong ciliated setæ. The exognath is simple and unjointed as in the second maxilliped, and on the outer surface of the basal joint is a pair of gills.

The First Leg (Pl. VII, Fig. 10) is the most prominent appendage of the animal at this stage. It is held pointing forwards, and when extended reaches almost half-way up the second antenna. The first three joints, of which the basal bears a pair of gills on its outer surface, are short and almost spineless. The fourth is very long and set with several short stout spines along the inner border, while near the end on the outer surface is a strong thorn-like spine.

The fifth joint is very short, and terminates on both its inner and outer side in a similar thorn. The sixth joint is somewhat flattened in the horizontal plane, and enlarged towards its distal part, where it ends 
on the outer border in a tooth-like spine ; on the inner edge it is produced forwards into the fixed finger of the chela, and forms a process almost as long as the seventh joint, broad at the base and tapering towards the point, bearing near the base on the inside three strong tooth-like projections or denticles. The whole joint is somewhat sparsely set with rather long spines, except the fixed finger which is bare, and on the inner surface near the base where there are three long barbed setæ.

The last and seventh joint forms the movable finger of the chela (the dactylus) ; it can be bent inwards towards the fixed finger, thus forming a strong and formidable pair of pincers, and is thickly set with rather strong spines.

The Second Leg (Pl. VII, Fig. 11) is about equal in length to the first but more slender. The basal joint, which bears a pair of gills, is rather short, as are also the two following joints; while the fourth is long, and bears near the end of the outer border a short stout spine. On its inner edge near the base, are two exceptionally long, forwardly curved and coarsely barbed setæ. The fifth joint is rather short, and has a thorn on its anterior inner edge, just behind which is inserted a seta similar to those on the preceding joint. The sixth joint is rather longer, and thickly set with strong spines on both borders, while at the base on the inner edge are four long curved setæ like those already described. The last joint is short and tapers to a point, where it terminates in a strong toothed spine. There are several scattered spines on its inner border, while along the outer edge is a dense row of spines, increasing in length from before backwards.

The following three pairs of legs (Pl. VII, Figs. 12-14) are all constructed on a plan similar to that of the limb just described; they decrease in size from the third to the fifth, and the spines are more sparsely set, but on none of them are there any of the specially long curved setæ such as are present on the second pair. On the outer surface of each leg except the last is a pair of gills.

The abdomen is broad and flattened dorso-ventrally; at the sides the membranous pleura of one segment slightly overlap those of the segment behind. The first three segments are sub-equal in length, the next two somewhat shorter, and the last is the longest of all.

The Pleopods (Pl. VIII. Fig. 1) are attached to the under surface of the four middle joints near their posterior border, and in a position of rest they point forwards beneath the abdomen. Each pleopod consists of a basal joint bearing two lobes, a long oval outer lobe, which is slightly bent inwards on the shaft, and a much smaller inner lobe or lappet, which points inwards towards its fellow of the opposite side. The longer lobe is surrounded by about thirty-one strong plumose setæ, and the tip and posterior edge of the inner lappet bears seven similar setæ, as well as one small seta on its anterior border near the base. 
The setæ on the inner lappets of the pleopods probably interlock with those of the opposite side, so as to make a more effective swimming paddle, and prevent independent movement.

The Uropods and Telson (Pl. VIII, Fig. 2) together form the "tailfan " of the animal. The telson is roughly rectangular in shape, rather longer than it is broad, and set along its posterior edge with plumose setæ.

The Outer Uropod is of an ellipsoid form, and is surrounded by a row of plumose setæ, and short scattered spines.

The Inner Uropod is a little shorter, and its weakly concave outer margin is bare, while the tip and the curved inner border are set with plumose setæ.

\section{Class B.}

\section{Second Post-larval Stage.}

After the first post-larval stage, the animal's development seems to pursue one of two alternative courses.

When a period of ten or twelve days has elapsed, it may either moult into a second post-larval form, of which the most distinctive characteristic is the presence of dense combs or fringes of setæ on the mouth parts and the inner borders of the first and second pairs of legs (Pl. IX, Figs. 1, 2) ; or it may moult into a second post-larval stage which resembles the first post-larval except for an increase in size, and in the number of setæ on certain appendages (e.g. the pleopods and the second maxilla). This unfringed second post-larval then moults into the fringed form, which may thus occur at either the second or third post-larval stage.

First post-larval stages of Class B were isolated in shallow glass dishes containing sea-water and a little fine sand or mud sprinkled on the bottom, and both fringed and unfringed second stages obtained, with the skins from which they moulted. In the case of the unfringed second postlarval forms, attempts to keep them alive until the third stage were not successful, but an examination of their appendages shows the formation beneath the cuticle of the dense rows of setæ characteristic of the animal in its fringed condition (Pl. VIII, Fig. 5).

A possible explanation of these facts is that through weakness due to artificial conditions or lack of proper food, the formation of the long fringes, necessitating the expenditure of a largə amount of reserve material, may be postponed until after the second moult.

This supposition receives some support from the fact that all the unfringed second post-larval forms died before moulting into the third or fringed stage.

NEW SERIES. - VOL. VII. NO. 1. JULY, 1919. 


\section{Class B.}

\section{Second Post-larval Stage. Fringed Form.}

This stage elosely resembles the corresponding stage in Class A, and in the case of eertain appendages, that form only has been figured.

It is about $4 \mathrm{~mm}$. in length, showing a definite increase in size on that of the last stage, and is altogether more robust and very much more setose than that form.

The First Antenna has much the same structure as before, but has increased in size.

The Second Antenna (Pl. VIII, Fig. 3) is slightly longer, the flagellum comprising eighteen joints, in place of the sixteen of the previous stage.

The Eyes are relatively smaller and closer together.

The Mouth parts are on the whole similar to those of the fringed stage of Class A (see description).

The First Leg (Pl. IX, Fig. 1) has two fringes on the inner border of the fourth joint, composed of plumose setæ of different lengths, those of the upper fringe being considerably shorter, and lying rather obliquely across the lower fringe, to form a kind of sieve. There is also a single comb of long plumose setæ on the inner surface of the sixth joint. Both. this and the following joint are thickly set with rather strong spines, and the fixed finger bears five denticles on the inside of the chela.

The Second Leg (Pl. IX, Fig. 2) also has two fringes on the inner border of the fourth joint, similar to those on the first leg, but the lower and longer fringe is continued in a curve over the fifth joint to its outer border. Along the inner margin of the sixth joint is a dense comb of long plumose setæ, and the outer edge of the last joint is set with a thick row of strong though rather short spines.

The remaining legs are similar to those of the preceding stage, but correspondingly longer.

The Pleopods show a distinct advance on the first stage in that the inner lappet is completely surrounded by a ring of about sixteen setæ.

The Telson is rather longer, and the uropods, especially the inner pair, considerably wider than before.

\section{Class B.}

\section{Second Post-larval Stage. Unfringed Form.}

This stage very closely resembles the first post-larval, but the following differences may be noted.

A definite increase in size has taken place, the animal now measuring just over $4 \mathrm{~mm}$. in length. 
The Rostrum reaches just to the level of the end of the eyes (Pl. VIII, Fig. 4) which are relatively smaller, and cover the second antenna only as far as the third joint of the shaft.

The Second Antenna appears to have twenty-six joints, although some of these are not very clearly defined.

The First Maxilla (Pl. VIII, Fig. 5) is figured as showing beneath the cuticle of the basal masticatory lobe, the developing spines of the fringed form.

The Second Maxilla (Pl. VIII, Fig. 6) has thirty-four spines on the exognath in place of the twenty-nine present in the last stage, and, moreover, this appendage shows a considerable inerease in size.

The First Maxilliped (Pl. VIII, Fig. 7) has five long curved setæ on the outer surface of the exognath, which is now definitely two-jointed.

The Legs (Pl. VIII, Fig. 8) are similar to those of the preceding stage, but larger, and they show no trace of the fringes which are so characteristic a feature of these appendages in the other second post-larval form.

\section{Class A.}

\section{First Post-larval Stage.}

This stage immediately succeeds the fourth larval stage, and bears a close resemblance to the corresponding first post-larval stage of Class B ; but it displays several minor points of difference which denote that it is at a slightly more advanced degree of development than Class B, a fact which might reasonably be expected from its having an extra larval stage.

The following are the chief differences between this stage and the same of Class B.

The animal measures $3.9 \mathrm{~mm}$., and the rostrum reaches to the level of the end of the eyes.

The Second Antenna has twenty-three joints in all, instead of only twenty.

The Second Maxilla (Pl. VIII, Fig. 9) has thirty-seven setæ on the exognath, in place of twenty-nine.

The First Maxilliped has five curved setæ on the outer surface of the exognath, being one more than in Class B.

The Second Maxilliped may have three long curved setæ on the outer surface of the penultimate joint, though this is not quite constant, as only two are sometimes present, as in Class B.

The First Leg (Pl. XII, Fig. 7) has a distinctly longer and more slender chela than Class B, and the fixed finger does not reach quite to the end of the dactylus, but springs from the sixth joint a short distance behind the tip. 
The Second Leg has five long curved setæ on the inner surface of the sixth joint, instead of only four.

The Pleopods generally have thirty-two setæ on the outer lobe.

\section{Class A.}

\section{Second Post-larval Stage.}

This stage is again closely comparable to the similar stage of Class B, i.e. the fringed second post-larval form. The animal measures just over $4 \mathrm{~mm}$. from the tip of the rostrum to the end of the telson, and the rostrum reaches slightly beyond the eyes, which conceal the first three joints of the second antenna.

The First Antenna has scarcely altered from that of the previous stage.

The Second Antenna comprises twenty-three joints in all, so that no increase in number has taken place.

The First Maxilla is similar in shape to that of the preceding stage, but the two masticatory lobes are much more thickly set with spines, particularly the basal lobe, which has a dense row of rather long spines all along its inner border (cf. Pl. IX, Fig. 5). At the base of the outer margin of the second masticatory lobe are attached two long curved setæ. The maxillary palp is still small, but bears a few scattered spines.

The Second Maxilla (Pl. IX, Fig. 3), although very like that of the preceding stage in shape, shows a great increase in its armature. The four masticatory lobes on the inner border are all thickly set with spines, and the basal lobe bears a second row, slightly within the edge. In addition, a new lobe or lappet has been developed, slightly in front of the hindmost lobe, and around its margin are seven plumose setæ. The exognath is well-developed, particularly at its lower end, where it terminates in a slight swelling, and the margin is set with about fortytwo spines. The maxillary palp shows no difference from the preceding stage.

The First Maxilliped (Pl. IX, Fig. 4) has also increased its armature. The basal masticatory lobe bears a number of curved spines, and the second lobe is thickly bordered along its inner margin with similar spines. The palp has a row of about eight finely barbed setæ on its inner edge, and the tip and outer margin of the exognath, now distinctly three-jointed, are set with a number of similar setæ.

The Second Maxilliped (Pl. VIII, Fig. 10) resembles that of the preceding stage in shape, but a thick row of spines borders the inner edge of the first two joints of the palp, and the last two joints are also densely set with more scattered spines. The unjointed exognath bears a double row of rather short ciliated setæ. 
The Third Maxilliped (ef. Pl. IX, Fig. 8) is thickly fringed with finely barbed setæ along the inner border of the palp, with the exception of the short third joint, so that the whole limb looks rather like a brush. All the joints bear scattered spines, and on the exognath are about six long setæ.

The Walking Legs are similar to those of the same stage in Class B, the two first pairs bearing the characteristic fringes of setæ, the remainder decreasing in size from before backwards.

The Pleopods bear thirty-one to thirty-three setæ on the outer lobe, and sixteen to twenty on the inner.

The Telson and Uropods have increased in width, particularly the inner pair of uropods.

\section{Class A.}

\section{Third Post-Larval Stage.}

Among the preserved post-larval specimens of Class A, two stages of the fringed form were found to be present, and, although absolute certainty is not possible as the moults were not obtained, it is extremely probable that the more advanced stage is the third post-larval of this class.

The length is nearly $4 \frac{1}{2} \mathrm{~mm}$., and the rostrum projects slightly beyond the eyes.

The First Antenna shows a definite advance, in that the third joint of the shaft is now divided into two, thus forming a four-jointed stem. The smaller of the two terminal processes or palps, also shows signs of division into two joints.

The Second Antenna (Pl. XI, Fig. 1) is composed of twenty-eight joints ; the rudiment of the antennal plate on the second joint is scarcely perceptible, while on the opposite side of the same joint is a row of seven long ciliated setæ.

The Mandible has increased its armature of spines on the palp, but is otherwise unchanged.

The First Maxilla (Pl. IX, Fig. 5) is like that of the previous stage, but even more setose.

The Second Maxilla (PI. IX, Fig. 6) again shows a definite advance on the last stage, both in size and complexity of structure. The masticatory lobes are still thickly bordered with spines, and the new lappet has increased in size and bears about ten setæ, while yet another lobe has arisen on the basal masticatory lobe, surrounded by about eight plumose setæ. The exognath is larger, and much swollen at the lower end, while the marginal setæ, numbering about forty-seven, now spread 
round the lower end and up the inner edge of the exognath. The maxillary palp bears three setæ, in place of the one hitherto present.

The First Maxilliped (Pl. IX, Fig. 7) is also definitely a stage in advance of the previous one. The spines on the larger of the two masticatory lobes are now divided into two longitudinal rows, slightly separated from each other; the palp is three-jointed, and the number of setæ, both on palp and exognath, has noticeably increased.

The Second Maxilliped is similar to that of the last stage (PI. VIII, Fig. 10), but slightly larger and more setose.

The Third Maxilliped (Pl. IX, Fig. 8) is also very similar to that of the second post-larval stage, but the exognath is two-jointed and bears numerous setæ, while a definite row of about five long ciliated setæ occurs on the outer border of the second joint of the palp.

The Legs resemble those of the last stage, but the fringes on the first two pairs are slightly longer.

The Pleopods bear nineteen to twenty-one setæ on the inner lappet.

The Uropods (Pl. IX, Fig. 9), particularly the inner pair, have again increased in breadth.

\section{UPOGEBIA STELLATA (Mont.).}

The larvæ of this species are also of common occurrence in the townets, but they are most abundant in the early summer (May and June) ; they fall off considerably in numbers during July, and are rarely found after the middle of August.

This indicates a rather earlier breeding season for the adults than is the case with Upogebia deltura, and this supposition gains some slight support from the fact that on an expedition to Salcombe on August 23rd, 1918, over a dozen specimens of the two species were taken, of which only two were Upogebia deltura, yet one of these two was a female in berry, and was the only berried female in the whole catch.

The first two post-larval specimens obtained during the experiments appeared from a moult on July 8th, and were both Upogebia stellata. Throughout the month of July numerous post-larval $U$. stellata were obtained from moultings. The first post-larval Upogebia deltura was obtained on Aug. 6th, and after that only one more post-larval specimen was $U$. stellata (Aug. 15th), the remainder were all $U$. deltura.

Thus the early collections of larvæ, made in May and June, were nearly all $U$. stellata, and similarly the later ones were almost entirely $U$. deltura. This served as a guide in the discrimination of the two species, and confirmation of the result was obtained by comparison with the first stage larvæ of Upogebia stellata hatched last year from a berried female in the Laboratory by Mr. De Morgan. 


\section{UPOGEBIA STELLATA (Mont.).}

\section{First Larval Stage.}

The larva in this stage is rather larger and more robust than the corresponding stage of Upogebia deltura. The appendages are very similar save for a slight but definite increase in size throughout, but the following constant differences may be noted.

The exognath of the Second Maxilla (Pl. X, Fig. 2) bears ten plumose setæ, instead of nine as in Upogebia deltura.

The First Maxilliped (Pl. X, Fig. 3) has a plumose seta on the outer surface of the second joint of the endopodite, in addition to that on the last joint, which is common to both species.

The coxopodite of the same limb may or may not bear the two coarsely barbed spines which are always present on this joint in Upogebia deltura Leach.

\section{Second Larval Stage.}

Two classes of larvæ, comparable to those found in the corresponding stage of Upogebia deltura may be distinguished amongst the larvæ of this stage in U. stellata.

Class A has four pairs of setose exopodites, from the first maxilliped to the first walking leg, while in Class B there are, in addition to these, four setæ on the exopodite of the second leg, making five pairs in all.

The general structure of the appendages is similar to that of the allied species $U$. deltura with the following constant differences.

The exognath of the Second Maxilla (Pl. X, Fig. 4) bears twelve plumose setæ instead of eleven, as is the general rule in $U$. deltura.

The plumose seta on the second joint of the endopodite in the First Maxilliped, which was a distinctive character of this species in the first stage, is still present; but in $U$. deltura this does not appear till the third larval stage.

The median " notch" on the hind margin of the telson is not flattened out, but remains distinct (Pl. X, Fig. 5).

\section{Third Larval Stage.}

The larva at this stage is very similar to that of Upogebia deltura, but may readily be distinguished from it by the following characteristics.

The general proportions of the body are rather different; the antennæ in front, and the last abdominal segment behind, being much larger in comparison with the rest of the animal. 
The total length may reach as much as $4 \frac{1}{2} \mathrm{~mm}$. The First Antenna has seven plumose setæ on the shaft.

The Second Maxilliped (Pl. X, Fig. 6) has developed a plumose seta on the second joint of the endopodite, corresponding in position to that on the first maxilliped, while the similar but smaller seta on the last joint seems to have disappeared.

The Telson (Pl. X, Fig. 7) is somewhat longer than that of the other species, and the hind margin is distinctly more concave.

The Uropods are longer, and the inner pair already jointed at the base, and in several specimens, tipped with a single plumose seta.

The larvæ comprised specimens displaying very various degrees of development of the pleopods and the endopodites of the thoracic limbs, as is also the case in the corresponding stage of $U$. deltura, a fact which suggests that the two classes of larvæ found in this stage of that species may also be traced in $U$. stellata.

Corroborative evidence of this is afforded by the fact that one of the first two post-larval specimens of Upogebia stellata, moulted (July 8th) from a larva with partly developed inner uropods-as in stage threebut at that time it was merely noted as an abnormality.

The light cast by the later experiments on the development of the allied species, Upogebia deltura, makes it seem most probable that the moult referred to above was that of a Class B third stage larva to the first post-larval stage.

\section{Fourth Larval Stage.}

This stage of Upogebia stellata is distinctly more slender in build than the corresponding stage of $U$. deltura, and in addition it presents the following differences in structural detail.

The First Antenna (Pl. X, Fig. 8) bears seven or eight plumose setæ instead of nine, and their arrangement differs slightly from that in U. deltura.

The Second Antenna (Pl. X, Fig. 9) bears thirteen setæ on the antennal plate.

The masticatory lobes of the First Maxilla are not so thickly set with spines.

The Second Maxilla bears about fourteen setæ on the exognath, instead of eighteen in $U$. deltura.

The Second Maxilliped displays the same distinctive seta as in the previous stage.

The Telson and Uropods (Pl. X, Fig. 11) are longer, and the hind margin of the telson somewhat more concave than in $U$. deltura.

The endopodites of the thoracic limbs are longer and more slender than those of $U$. deltura at this stage. 


\section{First Post-larval Stage.}

In the early summer of 1918, when the larvæ of Upogebia stellata were plentiful in the tow-nets, the occurrence of the moult from the third larval stage to the first post-larval in the other species was not known, and consequently no attempt was made to detect it in this species by isolating the larvæ and preserving the moults.

All the unfringed post-larval specimens were preserved together, but on examination they were found to fall naturally into two classes, according to the shape of the chela on the first leg.

Pl. XII, Fig. 5 is an example of Class A, Pl. XII, Fig. 6 of Class B ; a comparison of the two shows that the latter is characterised by a longer penultimate joint and dactylus, a larger fixed finger which points forwards and inwards towards the movable one, and bears one or more denticles on the inner surface, and in general by a more robust build.

In Class $\mathrm{A}$ there is a tendency for the fixed finger to spring from the sixth joint just below the level of the dactylus, which gives the last joint a somewhat pedunculated appearance; while the fixed finger projects outwards in a manner that suggests a rather ineffective grasping power.

Now these same characterictics may be seen in the chelæ of the two classes of larvæ in Upogebia deltura.

Pl. XII, Fig. 7 shows the chela in Class A, while members of Class B have a claw such as is figured in Pl. XII, Fig. 8. It will readily be seen that although the former figure is evidently drawn from a rather larger individual, yet it presents the general proportions characteristic of Class A, i.e. a slender penultimate joint, a dactylus which is narrow at the base and slightly pedunculate, and a less effective grip formed by the two fingers of the claw, due partly to the smaller size of the fixed finger, and partly to the smooth inner surface of the dactylus, which in Class B is roughened into points.

It is not only in the young stages, however, that these two kinds of claw may be distinguished; they are even more noticeable and distinct in the adults, where they form one of the secondary sexual characters.

It is not stated in the standard descriptions of these species that the chela of the first leg differs in the two sexes. Pl. XII, Figs. 9 and 10 are drawn to scale from a male and female Upogebia stellata of approximately the same length, and they show the striking difference which exists between the chelæ of the two sexes. (Spines and setæ not figured.)

The limb in the male is stout and broad; the fixed finger, which bears a denticle on the inside, is more than half as long as the movable one, and is evidently capable of acting as an efficient grasping organ. The 
movable finger or dactylus is strongly curved, broad at the base and tapering towards the point.

In the female, on the other hand, the limb is altogether of a more slender character; the fixed finger is much shorter and does not bend inwards towards the dactylus, which itself is much weaker in appearance and not nearly so broad at the base as that of the male.

On comparing Fig. 6 with Fig. 9, Fig. 5 with Fig. 10, it will be seen that the characters of the two sexes in the adult are foreshadowed almost exactly in the two types of chela displayed by the young post-larval stages, Class A resembling the female and Class B the male.

A comparison with the development of Upogebia deltura renders it probable that these two types in both species arise from the two classes of larvæ, which come from the third and fourth larval stages respectively; in which case the female has one more larval stage than the male, which moults directly from the third larval stage to the first post-larval.

As yet, however, all attempts to determine the sex of the young specimens have been unsuccessful, and their peculiar mode of life renders them particularly difficult to rear to maturity in the Laboratory, so that conclusions reached on this point are necessarily based on analogy, the present material not admitting of absolute proof.

The following is a description of the first post-larval stage of Upogebia stellata, taken from an individual of Class B.

The specimen measures $4 \frac{1}{2} \mathrm{~mm}$. in length from rostrum to telson; the rostrum reaches just beyond the eyes, which are relatively smaller than in Upogebia deltura at this stage.

The First Antenna is similar to that of the other species (see Pl. VII, Fig. 2).

The Second Antenna is composed of twenty-seven joints, the first four forming the shaft and the remainder the flagellum.

The Mandibles and First Maxilla are like those of Upogebia deltura, but the Second Maxilla (Pl. XI, Fig. 2) is considerably larger, and bears twenty-eight plumose setæ on the exognath.

The three pairs of Maxillipeds do not display any important differences from those of $U$. deltura.

The First Leg (Pl. XI, Fig. 3) is longer and more slender than the other species, and presents a striking contrast in the chela, of which the dactylus is long and tapering, while the fixed finger is very short, barely one-fifth the length of the dactylus and slightly toothed on the inner border.

The Second Leg (Pl. XI, Fig. 4) is like that of U. deltura, but bears five long barbed setæ on the fourth joint and five on the penultimate. 
The remaining thoracic limbs are similar to those of $U$. deltura, but more slender.

The Pleopods are composed of two lobes as in the other species, but of these the outer bears about twenty-eight setæ, and the inner five or six.

The Uropods and Telson (Pl. XI, Fig. 5) which together form the swimming tail-fan of the animal, are similar in general appearance to those of $U$. deltura, but the uropods are relatively longer, and the margins of both uropods and telson are set with long scattered spines, in addition to the regular row of plumose setæ.

\section{Second Post-larval Stage.}

The second post-larval stage of Upogebia stellata exhibits the same combs of setæ on the mouth parts and the two first pairs of thoracic legs as in the fringed stage of $U$. deltura, which it indeed closely resembles in structure ; the following points of difference, however, may be noted.

The total length from rostrum to telson is about $4 \frac{1}{2} \mathrm{~mm}$.

The Second Antenna generally consists of thirty-three joints.

The exognath of the Second Maxilla is bordered with about thirtynine plumose setæ.

The first and second Legs are similar to those of the previous stage, and the fringes of setæ are not quite so dense as in $U$. deltura.

The Pleopods have fourteen and thirty-five setæ on the inner and outer lobes respectively.

The Uropods (Pl. XI, Fig. 6) are longer and more slender than those of Upogebia deltura.

The following table has been drawn up to show the differences between the three forms, Gebia littoralis of Sars (1884), Upogebia deltura Leach, and Upogebia stellata (Mont.). 


\section{TABLE OF COMPARISON}

Stage.

Name of Part.

Gebia littoralis of Sars.

"About fourteen"

Absent

First Maxilliped. Seta on second joint of endopodite

Rudiments of Limbs behind second maxilliped

Larval
II

Setose exopodites

Second Antenna. Flagellum

Second Maxilla. Setæ on exognath

First Maxilliped. Seta on second joint of endopodite

Third Maxilliped. Terminal seta on endopodite

Abdominal Limbs

Telson. Median notch

Larval First Antenna. Setæ on

III shaft

Second Maxilliped. Seta on second joint of endopodite

Third Maxilliped. Terminal seta on endopodite

Outer Uropod. Marginal setæ

Inner Uropod. Terminal seta

Telson. Hind margin
Upogebia deltura Leach.

Nine

Absent

Six pairs

Class A. Four pairs Class B. Five pairs

Cut off

Eleven

Absent

Present

Class A. Absent

Class B. Present

Almost gone

Eight

Absent

Generally present

Generally fourteen

Absent

Weakly concave
Upogebia stellata (Mont.)

Ten

Present

Six pairs

Class A. Four pairs Class B. Five pairs Not cut off

Twelve

Present

Present

Absent

Still present

Seven

Present

Generally present

Generally thirteen

Sometimes present

Strongly concave 


\section{Larval IV}

Post-

I

shaft

exognath

Length
Gebia littoralis of Sars

\section{$5 \mathrm{~mm}$.}

Six

Second Maxilla. Setæ on

Second Maxilliped. Seta on second joint of endopodite

Colour

Rostrum. Length

Eyes

Second Antenna. Number of joints

Second Maxilla. Number of setæ on exognath

Arrangement of setæ

Chela. Lengths of fixed

finger and dactylus

Denticles on fixed finger

Inner Uropod. Outer border

\section{Twenty-two}

Not stated

$5 \mathrm{~mm}$.

Whitish

Beyond eye-level

Cover $2 \frac{1}{2}$ joints of second antenna

Twenty-three

Thirty-five

Massed at either end

Sub-equal

Five

Convex, with row of setæ
Upogebia deltura Leach

About $4 \mathrm{~mm}$.

Nine

\section{Eighteen}

Absent

Class A. About $4 \mathrm{~mm}$. Class B. About $3 \frac{1}{2} \mathrm{~mm}$.

Pale pink

Class A. Just to eye-level Class B. Not quite to eyelevel

Cover $5 \frac{1}{2}$ joints of second antenna

Class A. Twenty-three Class B. Twenty to

twenty-two

Class A. Thirty-seven

Class B. Twenty-nine

Evenly arranged

Sub-equal

Three

Weakly concave, bare of setæ
Upogebia stellata Mont.

About $4 \mathrm{~mm}$.

Seven or eight

\section{Fourteen}

Present

About $4 \frac{1}{2} \mathrm{~mm}$.

Pale pink

Beyond eye-level

Cover $2 \frac{1}{2}$ joints of second

antenna

Twenty-seven

Twenty-eight

Evenly arranged

Dactylus much longer than fixed-finger

One

Straight, bare of setæ 


\section{LITERATURE.}

1853. Bell, T. "British Stalk-eyed Crustacea," p. 222.

1903. Borradaile, L. A. "On the Classification of the Thalassinidea." Ann. Mag. Nat. Hist., Ser. 7, Vol. XII, p. 543.

1891. Cano, G. "Svilluppo postembrionale della Gebia, Axius, Callianassa e Calliaxis. Morfologia dei Talassinidi." Boll. Soc. Nat. in Napoli, Ser. I, Vol. V.

1910. De Morgan, W. "On the Species Upogebia stellata and Gebia deltura." Journ. Mar. Biol. Assoc., Vol. VIII, No. 5.

1825. Desmarest, A. G. " Considérations Générales sur la Classe des Crustacés."

1863. Heller, C. “Die Crustaceen des Südlichen Europa," p. 205, Taf. VI.

1813. Leach, W. E. "Crustacea." Edinburgh Encyclopædia, VII, p. 400.

1815. — "A tabular View of the external characters of Four Classes of Animals, etc." Trans. Linn. Soc., XI, p. 342.

1815-1817. — Malacostraca Podophthalmata Britanniæ, T. XXXI, Figs. 1-10.

1917. Lebour, M. V. "The Microplankton of Plymouth Sound." Journ. Mar. Biol. Assoc., Vol. XI, No. 2.

1893. Meinert, F. "Crustacea Malacostraca." "Hauch's" Togter, Text I, p. 221.

1868. Milne-Edwards, A. "Observations sur la faune carcinologique des îles du Cap Vert. Nouv. Arch. Mus. Hist. Nat., tome IV, p. 49.

1805. Montagu, G. "Description of several Marine Animals found on the South Coast of Devonshire." Trans. Linn. Soc., IX, T. III, Fig. 5, p. 89. 
1816. Risso, A. “Crustacés de Nice," p. 76, Pl. III, Fig. 2.

1884. Sars, G. O. "Bidrag til Kundskaben om Decapodernes Forvandlinger." Arch. Math. Naturw., IX, p. 182, Tab. 3-5.

1909. Stephensen, $K$. " Revideret Fortegnelse over Danmarks marine Arter af Decapoda." Vidensk. Meddel fra naturhist. Forening, 1907-1910, p. 277. 
Plate I. (All Figs. $\times 24$.)

FIG. 1. Upogebia deltura. First Larval Stage. Dorsal View.

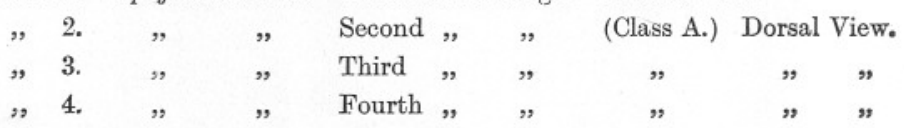


PLATE.I
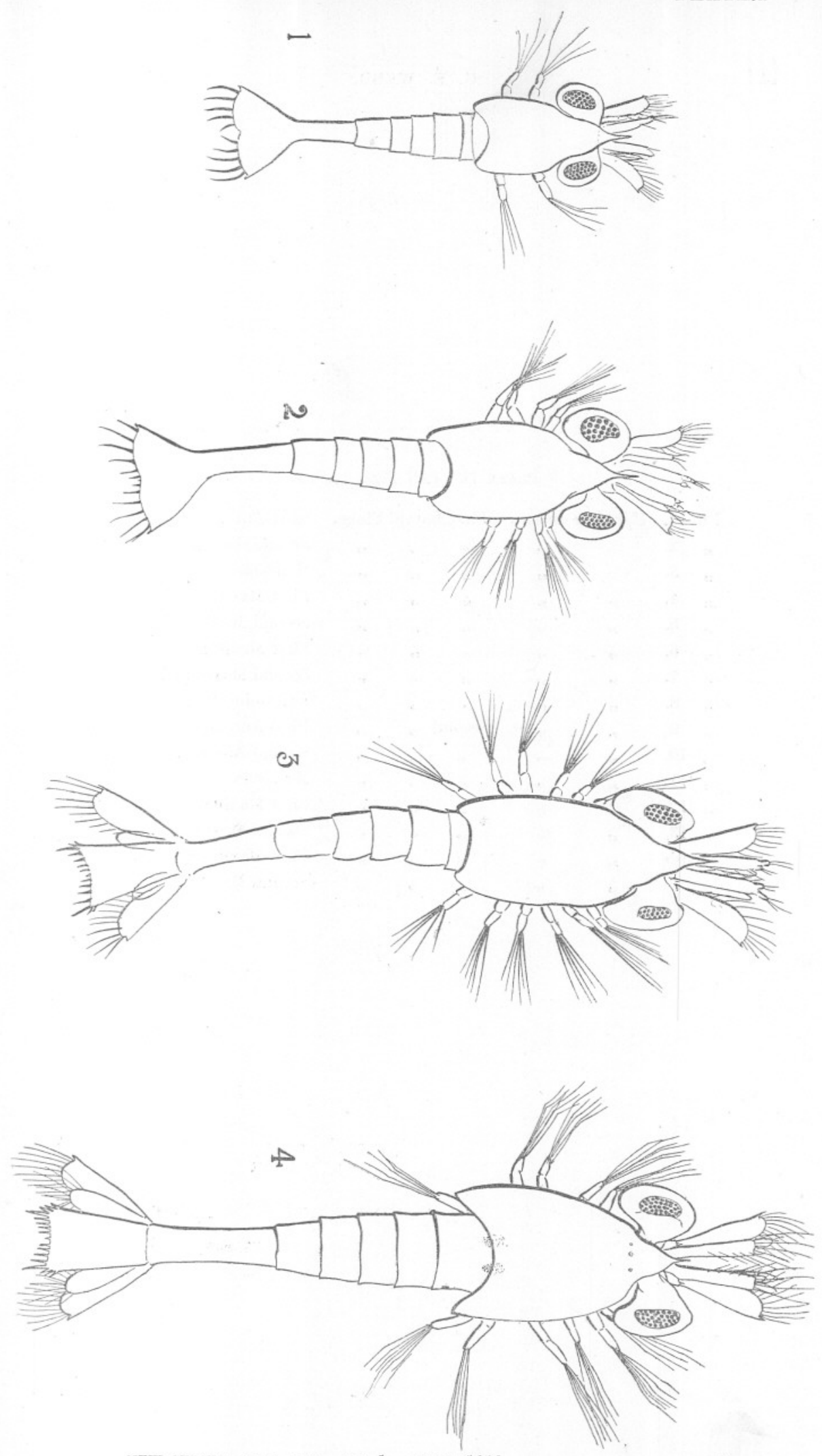

NEW SERIES. - VOL. XII. No. 1. JULY, 1919. 


\section{Plate li. (All Figs. $\times 70$.)}

Fic. 1. Upogebia deltura. First Larval Stage. First Antenna.

\begin{tabular}{|c|c|c|c|c|c|c|}
\hline$\Rightarrow 2$. & " & $"$ & $"$ & " & " & Second Antenna. \\
\hline 3. & , & $"$ & 2 & 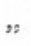 & $"$ & Mandible. \\
\hline 4. & , & $\%$ & " & $\eta$ & , & First Maxilla. \\
\hline 5. & $"$ & " & $"$ & , & , & Second Maxilla. \\
\hline 6. & $"$ & " & $"$ & " & $\because$ & First Maxilliped. \\
\hline 7. & " & $n$ & $"$ & , & $"$ & Second Maxilliped. \\
\hline 8. & $"$ & $"$ &. & " & , & Swimming Plate. \\
\hline 9. & $\eta$ & $"$ & Second & , & $"$ & First Antenna. \\
\hline, 10. & $"$ & $"$ & $"$ & $"$ & " & Second Antenna. \\
\hline " 11. & $"$ & $"$ & $"$ & " & , & Mandible. \\
\hline ", 12. & $"$ & " & $"$ & , & " & First Maxilla. \\
\hline 13. & " & $"$ & " & " & $"$ & Second Maxilla. \\
\hline 14. & $"$ & $"$ & $"$ & " & $"$ & First Maxilliped. \\
\hline 15. & $"$ & $"$ & 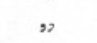 & " & " & Second Maxilliped. \\
\hline
\end{tabular}


PLATE II.
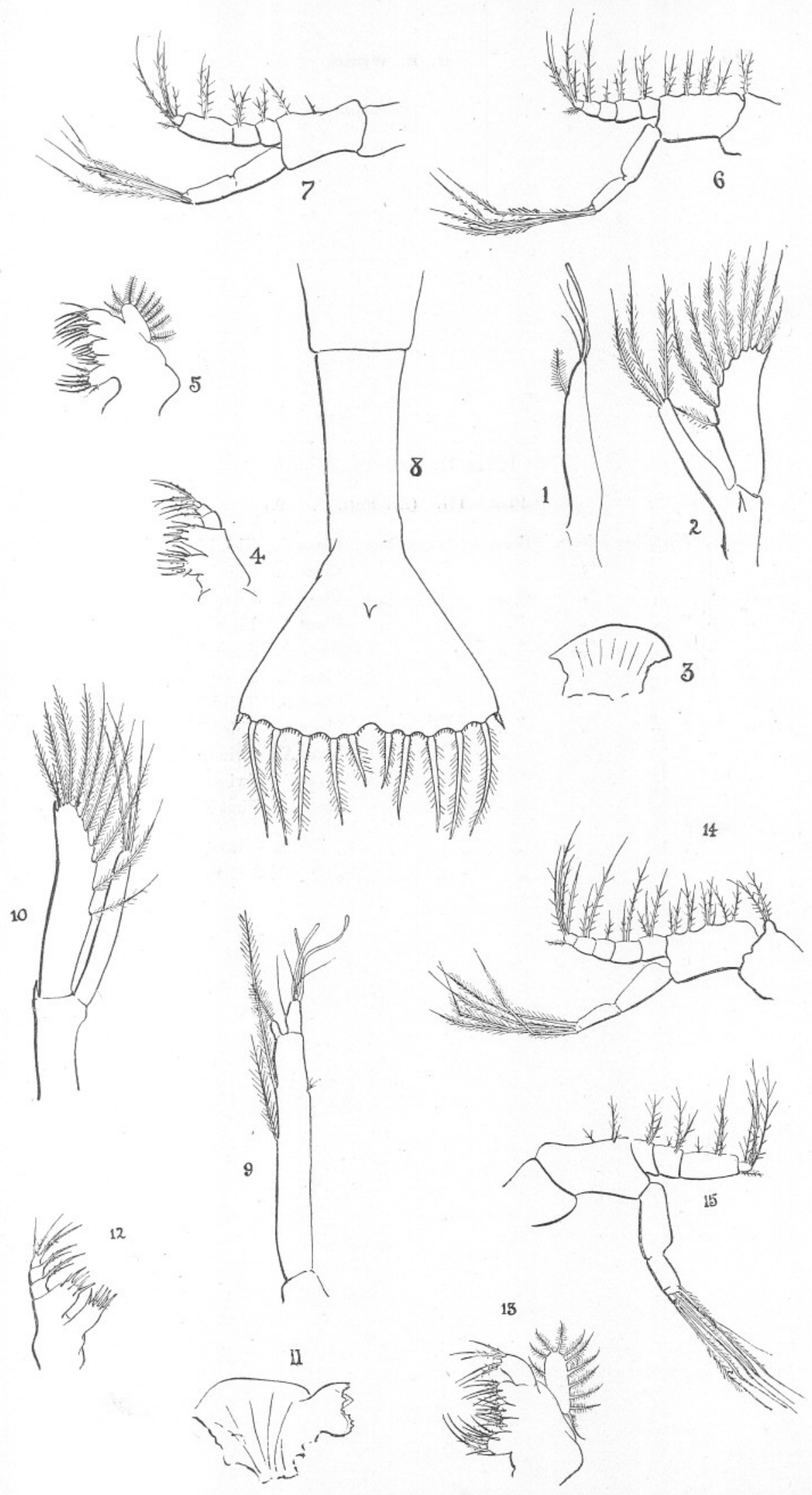
Plate III. (All Figs. $\times 70$.)

FIg, 1. Upogebia deltura. Second Larval Stage. Class B. Third Maxilliped.

, 2. " " " " , , $\quad$ "Class A. Third Maxilliped.

"3. $\quad$ " $\quad, \quad, \quad, \quad, \quad$ Class B. First Leg.

"4. " , , , , , , , Class A. First Leg.

"5. " ",$\quad$, $\quad$, " Class B. Second Leg.

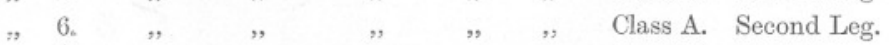

"7. " , , , , , , Class B. Third Leg.

" $8 . \quad " \quad$ " " " ,,$\quad$ Class A. Third Leg.

"9. " " , , , " $\quad$, Class A. Swimming Plate.

"10. , , " , , " Class B. Swimming Plate.

" $11 . \quad, \quad, \quad, \quad, \quad$, Class B. First Three Abdominal Seg-

[ments with Pleopods 

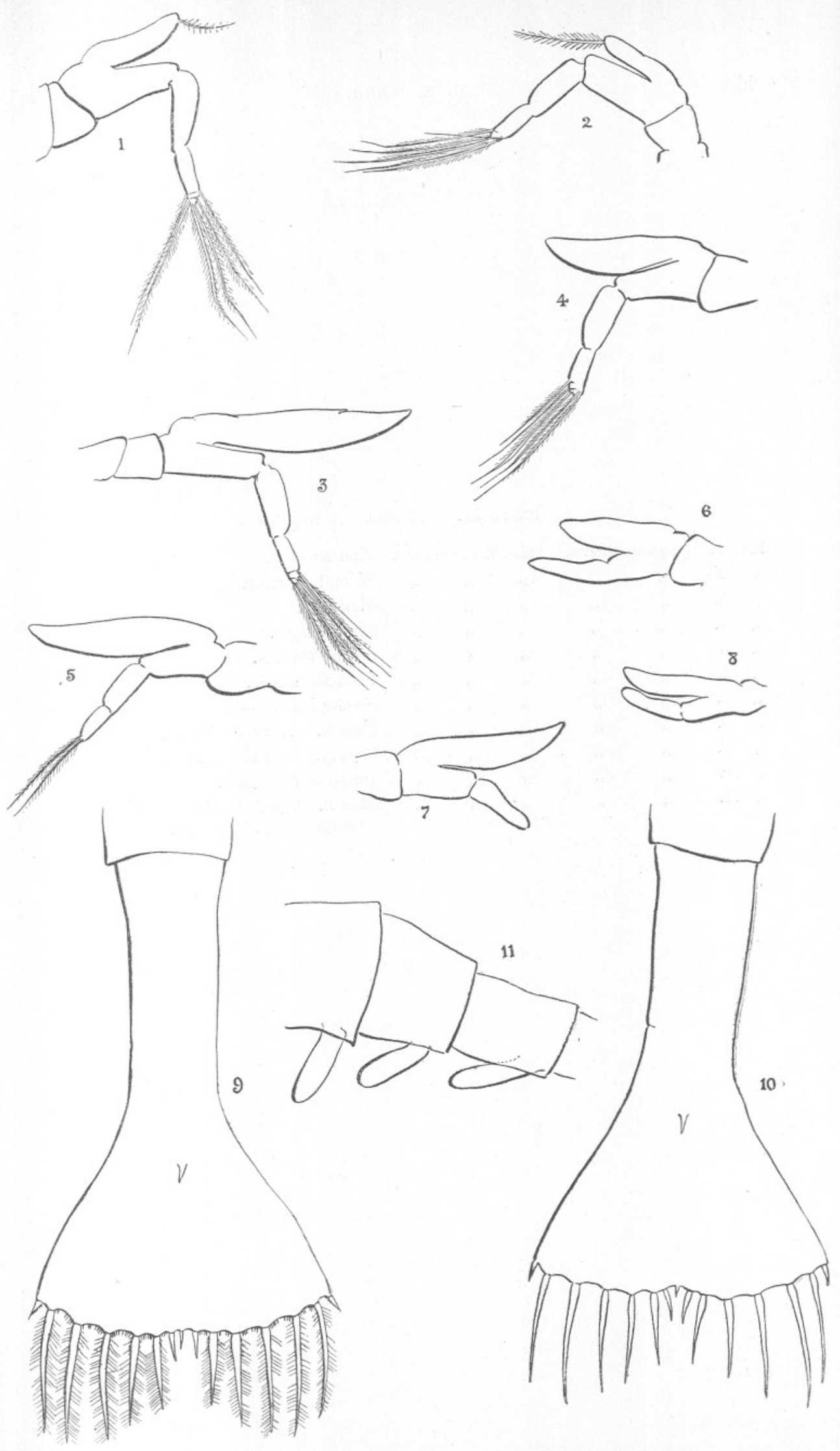
Plate IV. (All Figs. $\times 70$.

Fig. 1. Upogebia deltura. Third Larval Stage. First Antenna.

\begin{tabular}{|c|c|c|c|c|c|}
\hline$\Rightarrow \quad 2$. & ", & $"$ & " & ") & " \\
\hline 3. & " & " & $"$ & $"$ & $"$ \\
\hline 4. & " & $"$ & $"$ & ", & ", \\
\hline 5. & " & $"$ & ", & ", & $"$ \\
\hline 6. & ", & $"$ & ", & ", & ", \\
\hline 7. & ", & " & $"$ & ", & " \\
\hline 8. & $\because$ & " & $"$ & " & ", \\
\hline " 9. & " & " & $"$ & " & " \\
\hline, 10. & $"$ & " & 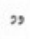 & $"$ & $"$ \\
\hline 11. & " & " & , & " & " \\
\hline
\end{tabular}
Second Antenna. Mandible. First Maxilla. Second Maxilla. First Maxilliped. Second Maxilliped. Class B. Third Maxilliped. Class A. Third Maxilliped. Telson and Uropods. Class B. Third Maxilliped and Five [Thoracic Legs. (Exopodites dotted.) 
Plate V. (All Figs. $\times 70$.)

Frg. 1. Upogebia deltura. Third Larval Stage. Class B. First Leg.

\begin{tabular}{|c|c|c|c|c|c|c|}
\hline, 2. & ", & $"$ & , & " & ", & Class A. First Leg. \\
\hline 3. & " & ", & ", & " & $"$ & Class B. Second Leg. \\
\hline 4. & $\%$ & , & , & , & " & Class A. Second Leg. \\
\hline 5. & " & , & $"$ & " & , & Class B. Third Leg. \\
\hline 6. & $"$ & , & $"$ & , & ", & Class A. Third Leg. \\
\hline 7. & , & \% & Fourth & " & 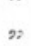 & Second Antenna. \\
\hline 8. & " & $"$ & $"$ & $"$ & " & First Maxilla. \\
\hline 9. & " & , & $"$ & " & , & Second Maxilla. \\
\hline 10: & " & " & , & , & , & Uropods and Telson. \\
\hline
\end{tabular}


PLATE $V$

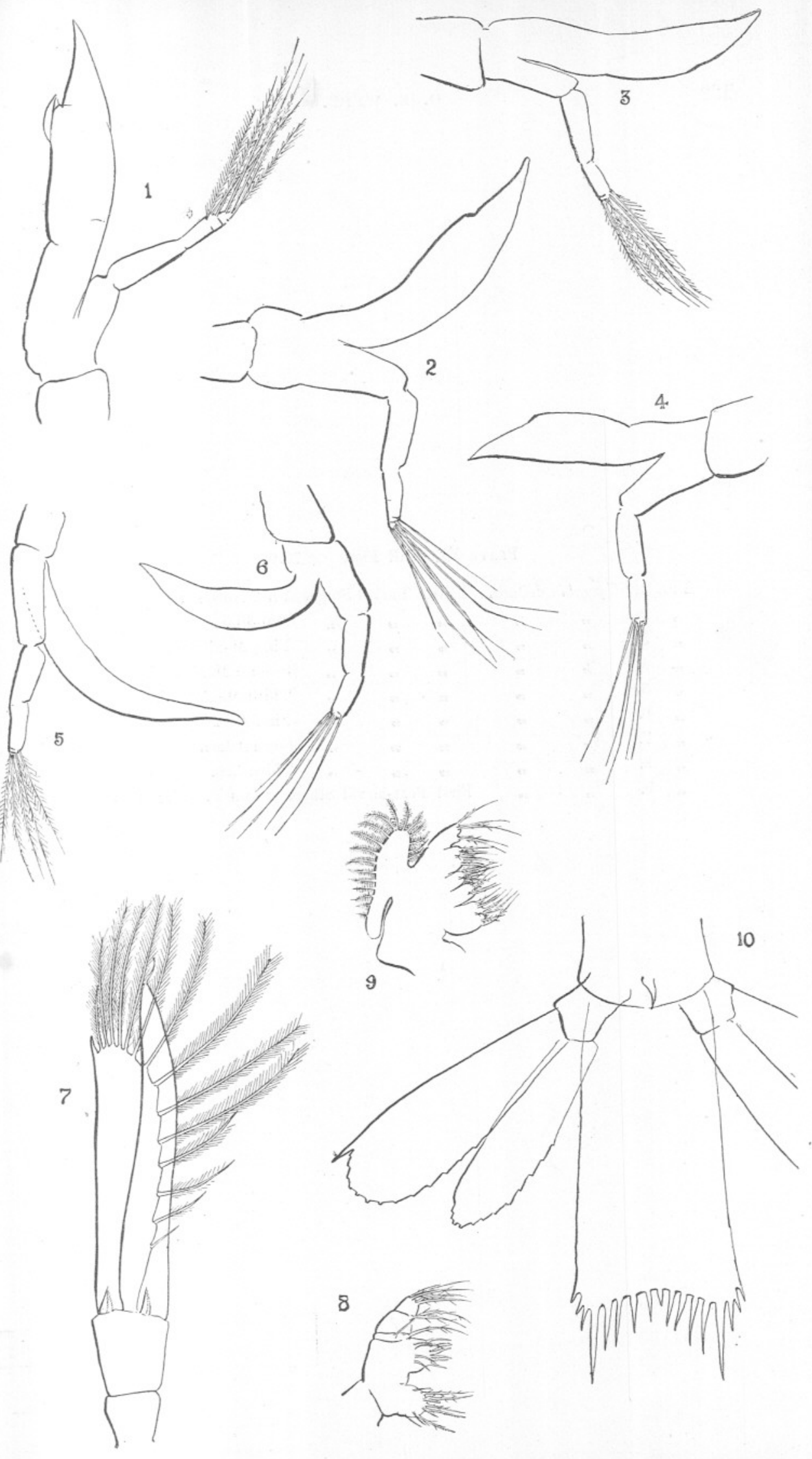


Plate VI. (All Figs. $\times 70$.

FIG. 1. Upogebia deltura. Fourth Larval Stage. First Antenna.

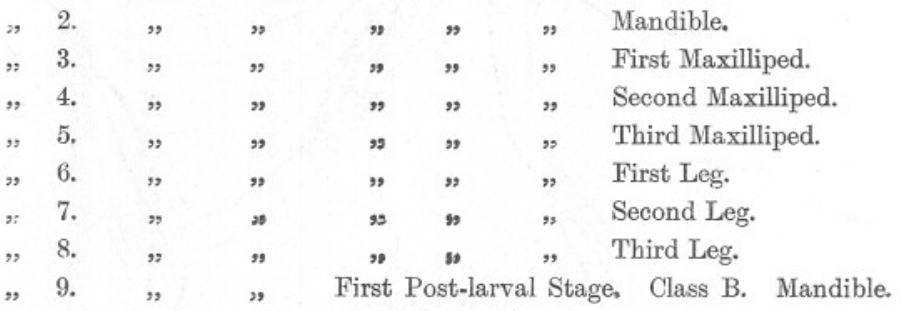


PLATE VI.
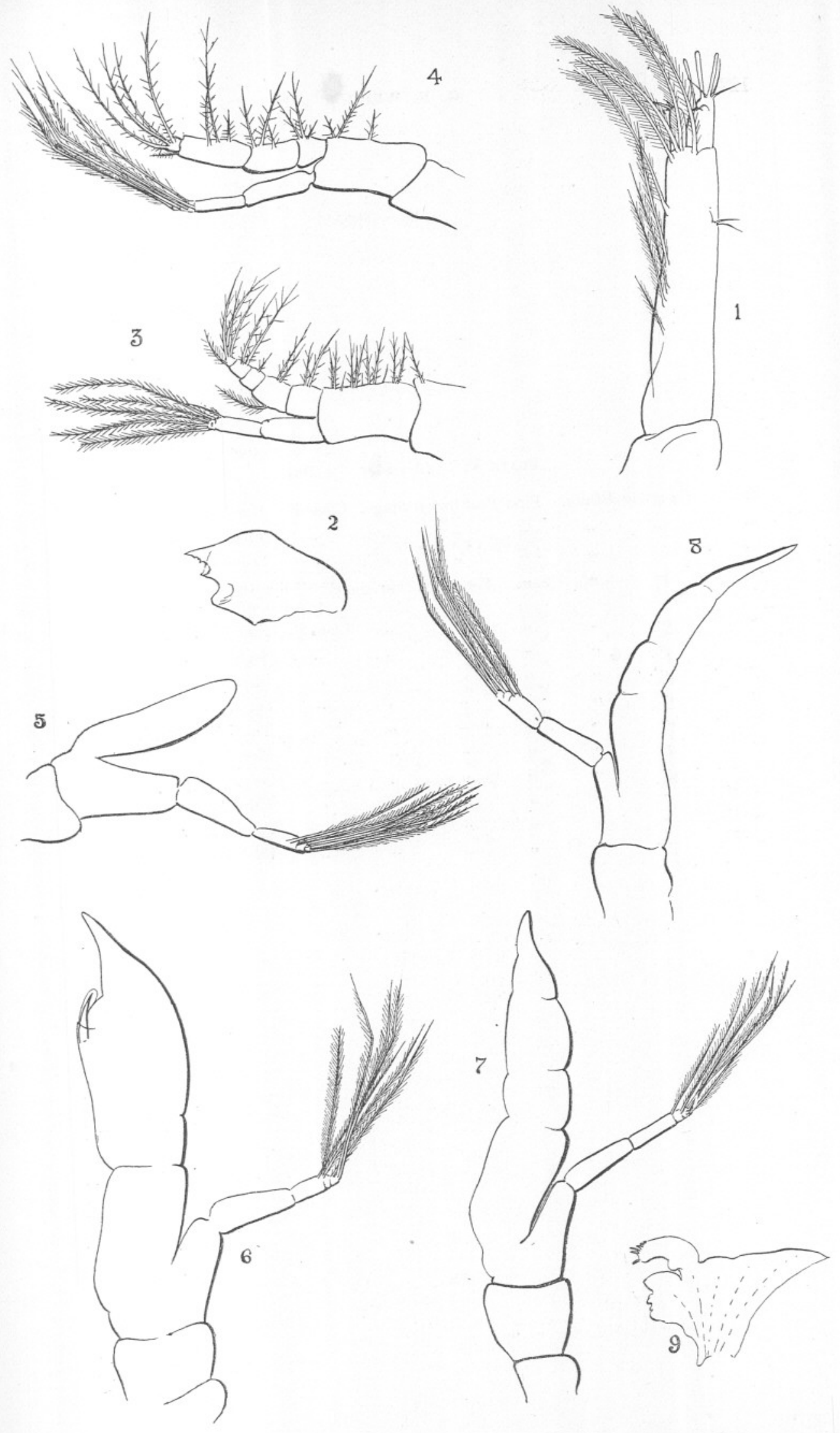
Plate VII. (All Figs. $\times 70$.)

Fig. 1. Upogebia deltura. First Post-larval Stage. Class Be Rostrum.

\begin{tabular}{|c|c|c|c|c|c|c|c|}
\hline 2. & , & , & $"$ & $"$ & , & $"$ & First Antenna. \\
\hline 3. & $\because$ & $"$ & ", & , & , & $\Rightarrow$ & Second Antenna. \\
\hline 4. & , & $"$ & , & " & " & $\begin{array}{r}\text { Rostrum } \\
\text { relatior }\end{array}$ & $\begin{array}{l}\text { removed to show } \\
\mathrm{n} \text { of eyes and antennæ. }\end{array}$ \\
\hline 5. & " & \% & " & $"$ & ", & Class B. & First Maxilla. \\
\hline 6. & " & ” & " & " & " &, & Second Maxilla. \\
\hline 7. & $"$ & , & $"$ & " & " & ", & First Maxilliped. \\
\hline 8. & ", & $"$ & " & " & ", & , & Second Maxilliped. \\
\hline 9. & $"$ & " & " & $"$ & , & " & Third Maxilliped. \\
\hline , 10. & $"$ & , & , & $"$ & , & , & First Leg. \\
\hline , 11. & $"$ & $"$ & " & " & " & " & Second Leg. \\
\hline 12. & , & $"$ & , & $n$ & ", & , & Third Leg. \\
\hline 13. & $"$ & $"$ & $"$ & " & " & , & Fourth Leg. \\
\hline 14. & $"$ & ", & , & $"$ & , & , & Fifth Leg. \\
\hline
\end{tabular}


PLATE VII.

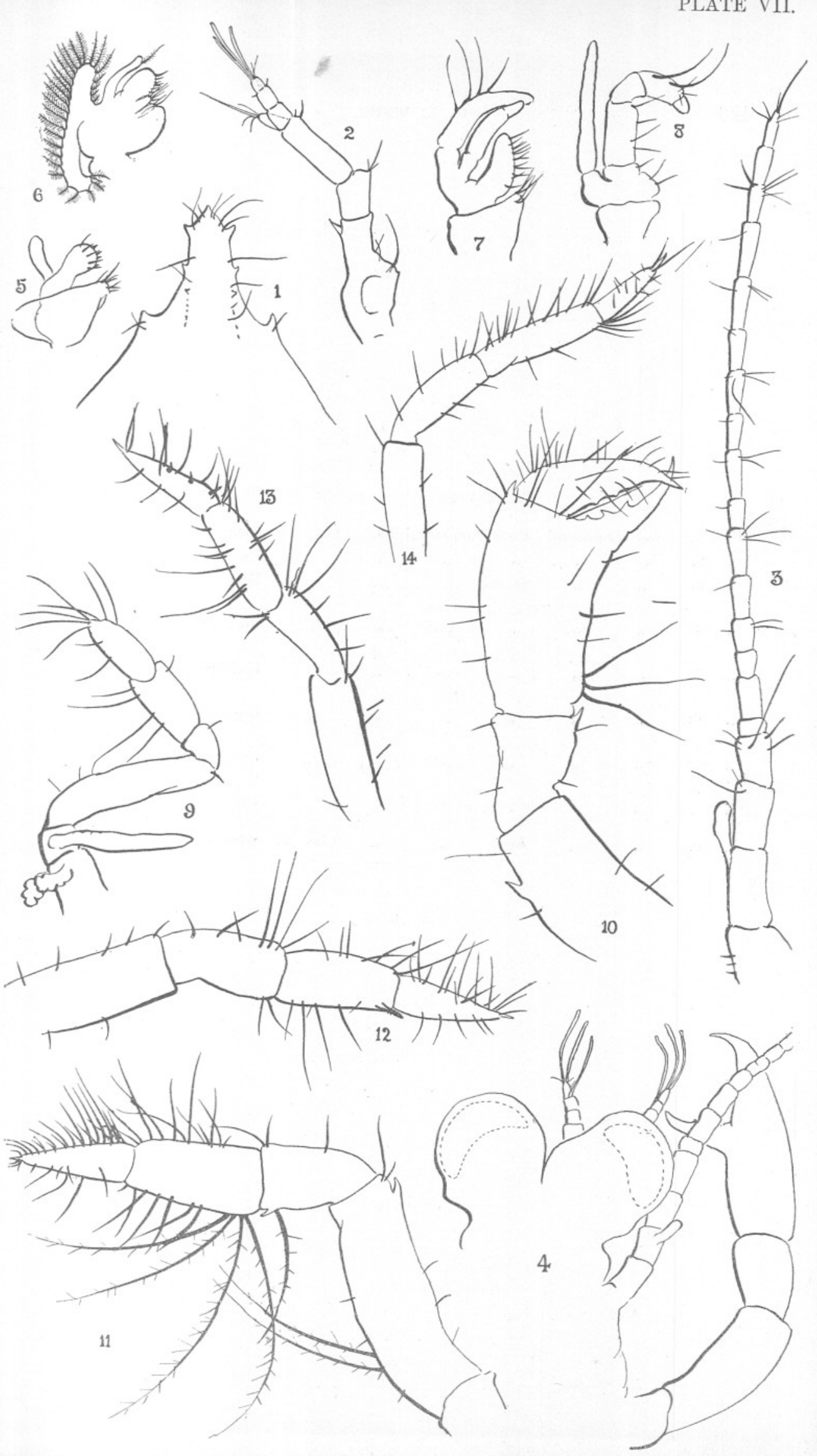


G. E. WEBB.

Plate VIII. (All Figs. $\times 70$.)

Fig. 1. Upogebia deltura. First Post-larval Stage. Class B. Pleopod.

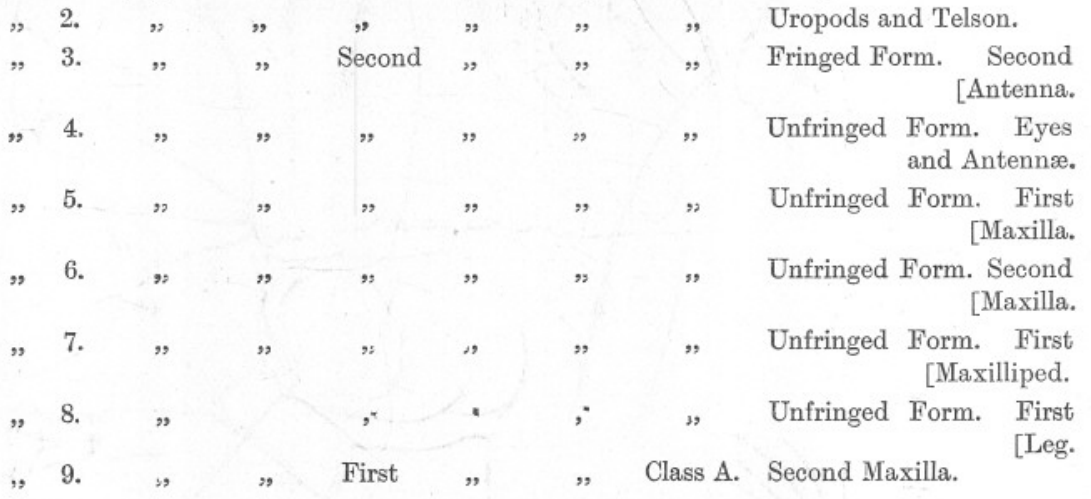


G. E. WEBB.

Plate IX. (All Figs. $\times 70$.)

FIG. 1. Upogebia deltura. Second Post-larval Stage. Class B. Fringed Form. First

\begin{tabular}{|c|c|c|c|c|c|c|c|}
\hline 2. & " & $"$ & $"$ & $"$ & " & $"$ & Fringed Form. Seco \\
\hline 3. & ", & $"$ & $"$ & ", & $"$ & Class A. & Second Maxilla. \\
\hline 4. & , & " & ", & $"$ & , &, & First Maxilliped. \\
\hline 5. & " & , & Third & " & , & $"$, & First Maxilla. \\
\hline 6. & ", & " & ", & 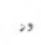 & , & $"$ & Second Maxilla. \\
\hline .7. & " & $\eta$ & " & " & , & , & First Maxilliped. \\
\hline 8. & " & $"$ & $"$ & $"$ & $"$ & $"$ & Third Maxilliped. \\
\hline 9. & " & $"$ & ", & $"$ & ” & $"$ & $\begin{array}{l}\text { Telson and Uropods. } \\
\text { (Spines omitted.) }\end{array}$ \\
\hline
\end{tabular}


PLATE IX.

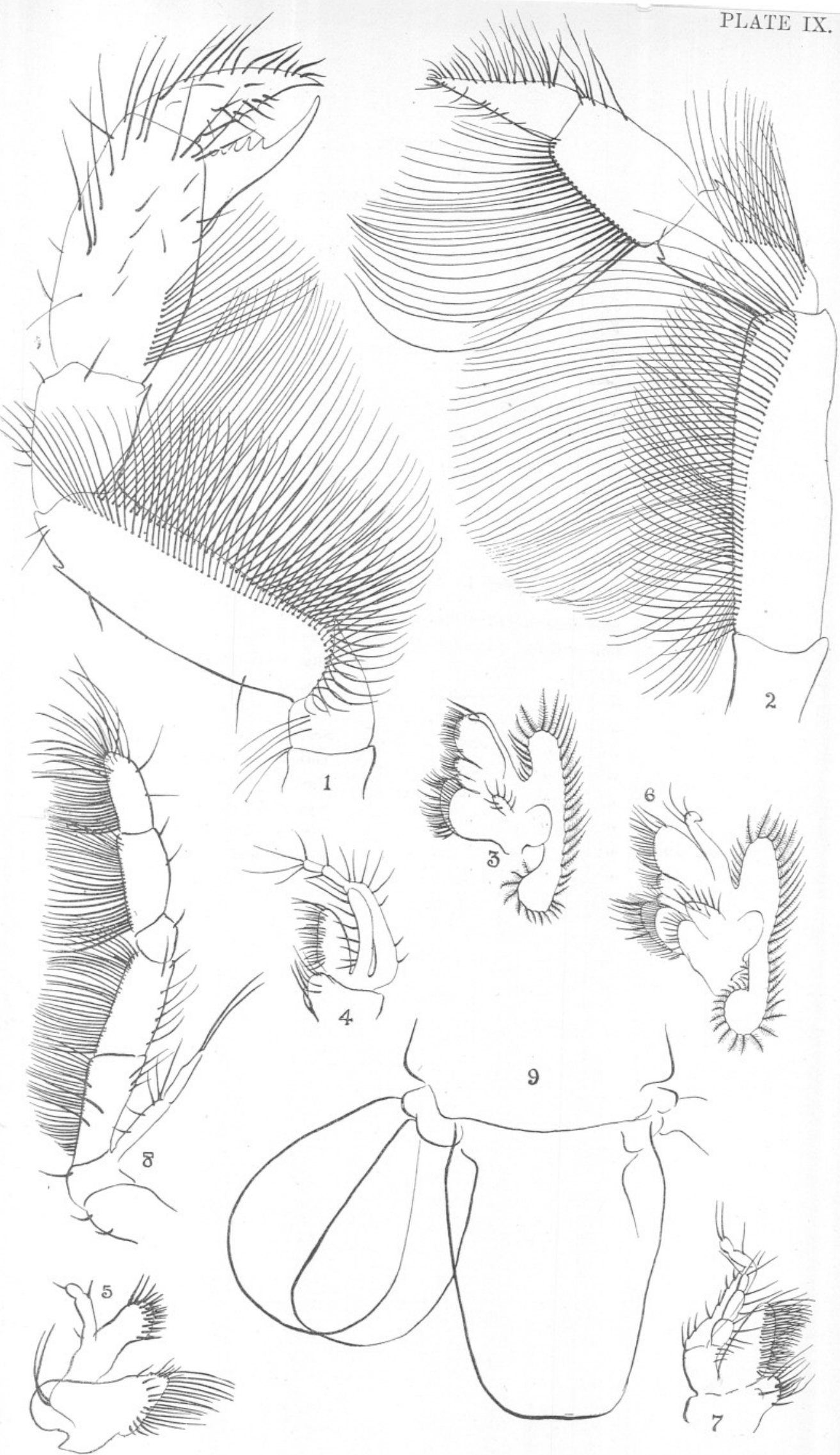

NEW SERIES.-VOL. XII. NO. 1. JULY, 1919. 
Plate X. (Fig. 1. $\times 24$. Figs, 2-11. $\times 70$.

Fig. 1. Upogebia deltura. First Post-larval Stage. Class B. Dorsal View.

, 2. Upogebia stellata. First Larval Stage. Second Maxilla.

, , , ,

Second , , ,

, , , ,

Third , ,

, , , ,

Fourth , ,

, , , ,

, , ,

, , ,
First Maxilliped.

Second Maxilla.

Swimming Plate.

Second Maxilliped.

Telson and Uropods.

First Antenna.

Second Antenna.

First Maxilla.

Uropods and Telson. 
Plate XI. (All Figs. $\times 70$.)

Fig. 1. Upogebia deltura. Third Post-larval Stage. Class A. Second Antenna.

"2. Upogebia stellata First " " , Second Maxilla.

, $3 . \quad, \quad, \quad$,

,4. $4 ., \quad, \quad, \quad$,

"5. $, \quad, \quad, \quad$,

, 6. , , , Second ,

" Class B. First Leg.

, $\quad$ Second Leg.

, Uropods and Telson.

,

(Spines omitted.) 
PLATE XI.

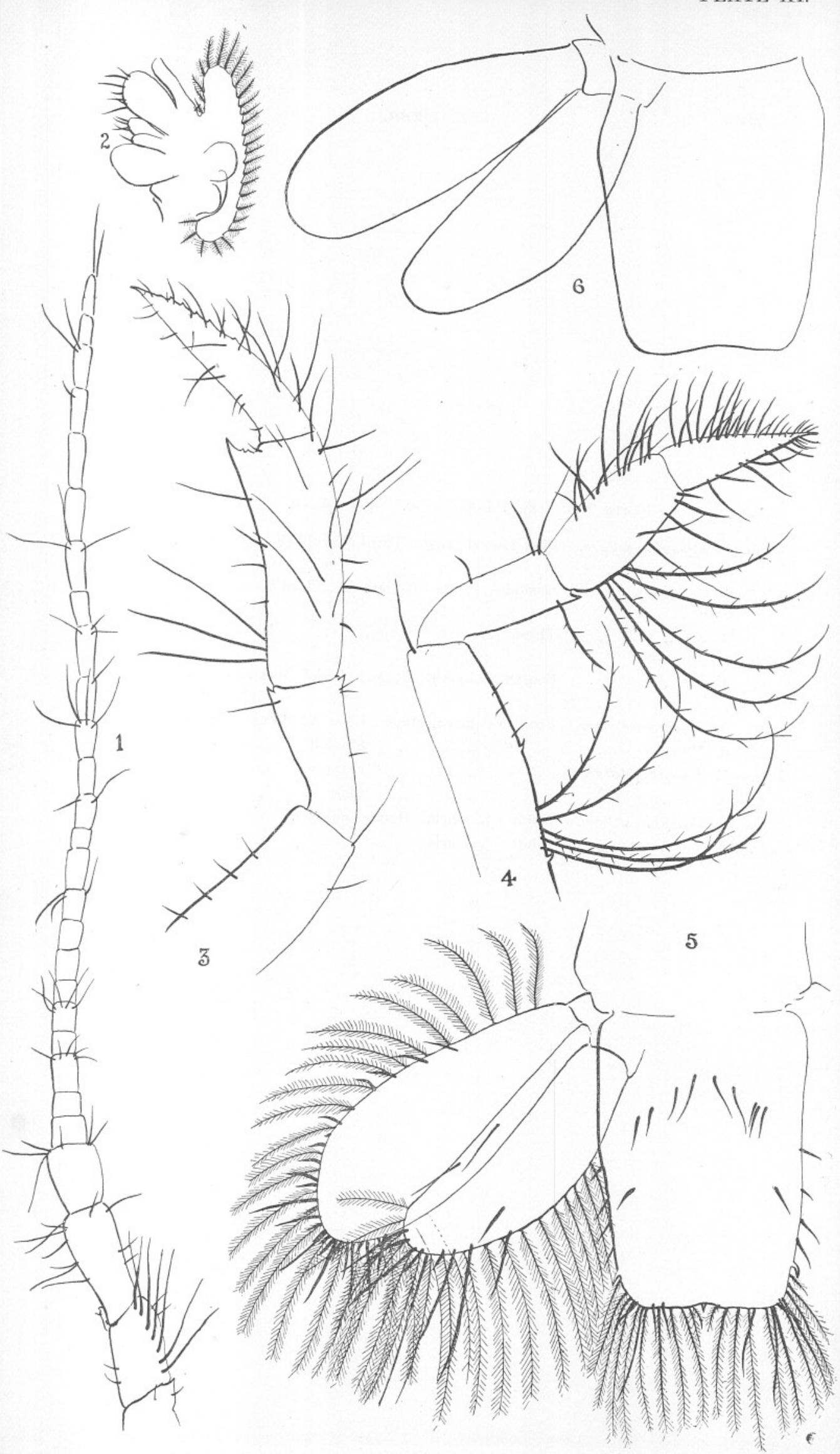


Plate XII. (Figs. 1-8. $\times 70 . \quad$ Figs. 9, $10 . \times 3 \frac{1}{4}$.)

Fic. 1. Upogebia deltura. First Larval Stage. Third Maxilliped to Fifth Leg. (Exopo[dites dotted.) , 2. $\quad, \quad$ " Second , $\quad$, Class A. Third Maxilliped to Fifth Leg.

[(Exopodites dotted.)

, $3 . \quad, \quad$ " $\quad$ Third $\quad, \quad, \quad, \quad$, Maxilliped to Fifth Leg.

[(Exopodites dotted.)

" 4. " " Fourth Larval Stage. Third Maxilliped to Fifth Leg.

[(Exopodites dotted.)

„5. Upogebia stellata. First Post-larval Stage. Class A. Chela. Spines omitted.

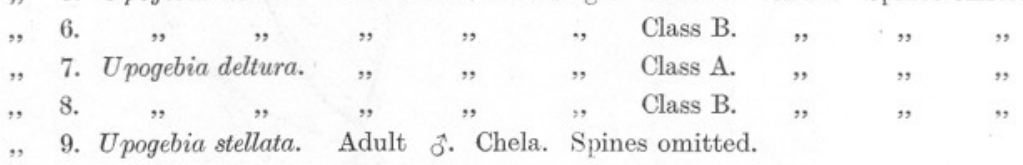

, 9. Upogebia stellata. Adult o. Chela. Spines omitted.

, $10 . \quad, \quad, \quad$ Adult ‥ Chela. 
